DOI: https://doi.org/10.47405/mjssh.v6i10.1105

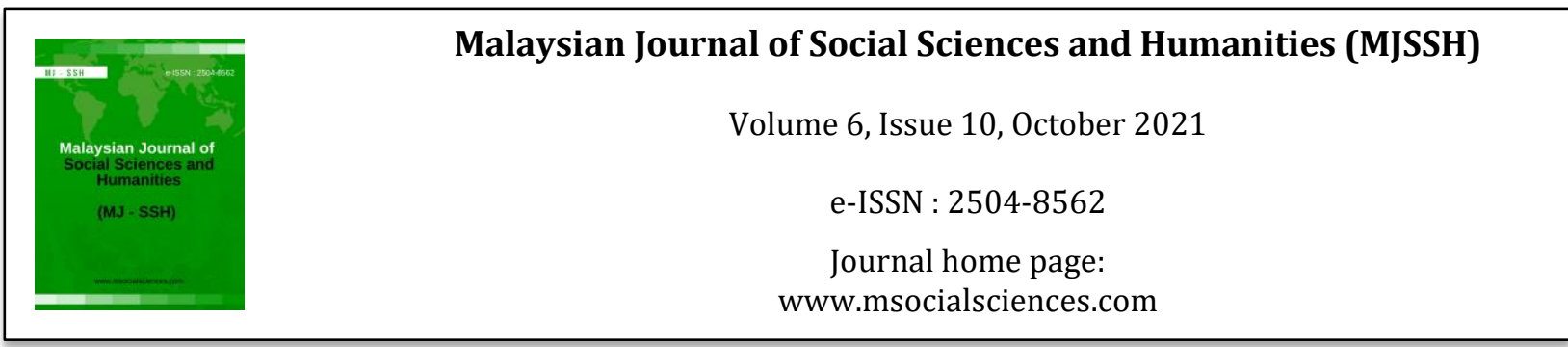

\title{
Hubungan Kelayakan Akademik dan Pengalaman Mengajar dengan Tahap Efikasi Kendiri Guru Prasekolah Menjalankan PDPC Pasca Pandemik Covid-19
}

\author{
Hanassia Andoh ${ }^{1}$, Connie Cassy Ompok ${ }^{1}$, Nur Suhaidah Sukor ${ }^{1}$ \\ 1Fakulti Psikologi dan Pendidikan, Universiti Malaysia Sabah (UMS), Kota Kinabalu, Sabah, Malaysia \\ Correspondence: Hanassia Andoh (hanassiaandoh@gmail.com)
}

\begin{abstract}
Abstrak
Kajian ini dijalankan bagi mengenal pasti hubungan kelayakan akademik dan pengalaman mengajar dengan tahap efikasi kendiri guru prasekolah menjalankan pengajaran dan pemudahcaraan (PdPc) di kelas prasekolah pada pasca pandemik Covid-19. Saiz sampel $(n=74)$ ditentukan melalui formula penentuan saiz sampel Krejcie-Morgan (1970), dan dipilih secara rawak di kalangan guru prasekolah Jabatan Kemajuan Masyarakat (KEMAS) Daerah Ranau. Data dikutip melalui kaedah soal selidik dengan menggunakan instrumen Teacher's Sense of Efficacy (TSES) yang dibangunkan oleh Tschannen-Moran \& Hoy (2001), dan kemudiannya dianalisis menggunakan SPSS v20.0. Analisis deskriptif menunjukkan efikasi kendiri guru berada pada tahap sederhana tinggi dengan catatan $\mathrm{M}=3.69, \mathrm{SD}=0.59$. Korelasi Pearson mendapati adanya hubungan tidak signifikan di antara kelayakan akademik dan pengalaman mengajar dengan efikasi guru kerana dapatan $\mathrm{K}>.05$ bagi kedua-dua pemboleh ubah. Dapatan ini menunjukkan, efikasi kendiri guru menjalankan PdPc pasca pandemik Covid-19 tidak ditentukan oleh kelayakan akademik dan pengalaman mengajar. Namun begitu, jika dilihat daripada domain efikasi didapati bahawa pengalaman mengajar mempunyai korelasi dengan efikasi pengurusan kelas dengan dapatan kajian $\mathrm{r}=.236, \mathrm{k}<.05$.
\end{abstract}

Kata kunci: efikasi kendiri, guru prasekolah, pandemik Covid-19

\section{The Relationship Between Academic Qualification and Teaching Experience Towards Preschool Teacher Self-Efficacy on Carrying Out Teaching and Facilitation During Post Covid-19 Pandemic}

\begin{abstract}
The purpose of this study was to identify the relationship between academic qualification and teaching experience towards preschool teacher self-efficacy on carrying out teaching and facilitation during post covid-19 pandemic. Sample size $(n=74)$ are fixed based on Krejcie-Morgan sampling size formula (1970), respondents are selected randomly amongst preschool teacher from The Department of Regional Development (KEMAS) in Ranau district. Raw data obtained through questionnaire, which utilize the Teacher's Sense of Efficacy (TSES) by Tschannen-Moran \& Hoy (2001), and analyzed by SPSS v20.0. Descriptive analysis showed that, teacher self efficacy were at medium high level whereas $\mathrm{M}=3.69$, $\mathrm{SD}=0.59$. Pearson Correlation shows unsignificant relationship between academic qualification and teaching experience towards teacher efficacy as $K>.05$ for both variables. This finding indicate that teacher sense of efficacy to carry out teaching and facilitation in class amid post Covid-19 pandemic are not determined by academical qualification and teaching experience. However,
\end{abstract}


by looking through domain of efficacy, it shows that teaching experience do correlate with efficacy in class management whereas $\mathrm{r}=.236, \mathrm{k}<0.05$.

Keywords: Self efficacy, preschool teacher, Covid-19 pandemic

\section{Pengenalan}

Pendidikan prasekolah di Malaysia merupakan suatu program pendidikan awal kanak-kanak untuk kanak-kanak berusia empat hingga enam tahun. Ia dilindungi di bawah Akta pendidikan 1996 (Akta 550). Agensi yang menyediakan program pendidikan prasekolah di negara ini termasuklah agensi awam seperti Kementerian Pendidikan Malaysia (KPM) untuk prasekolah KPM, Kementerian Pembangunan Luar Bandar (KPLB) untuk Tabika KEMAS, Kementerian perpaduan Negara untuk Tabika Perpaduan, prasekolah di bawah seliaan kerajaan negeri seperti Prasekolah JAIS di Selangor, serta prasekolah daripada badan bukan kerajaan (NGO) seperti PACOS Trust, dan pelbagai agensi swasta. Sesuai dengan seksyen 22 dalam Akta Pendidikan 550, setiap pendidikan prasekolah di Malaysia mengguna pakai kurikulum yang sama iaitu Kurikulum Standard Prasekolah Kebangsaan (KSPK) yang dikemas kini dari masa ke semasa. Walaupun menggunakan kurikulum yang sama, setiap institusi pendidikan prasekolah bebas menggunakan pendekatan pembelajaran berbeza serta aplikasi pelbagai teori bidang pendidikan awal kanak-kanak.

Akses sama rata ke atas pendidikan prasekolah hingga menengah yang berkualiti, berekuiti dan cekap merupakan antara matlamat keberhasilan sistem pendidikan Malaysia, dalam Pelan Pembangunan Pendidikan Malaysia 2013-2025 (Kementerian Pendidikan Malaysia , 2013). Justeru itu dalam bidang pendidikan awal kanak-kanak, pelbagai usaha dan insentif telah dibuat sama ada dari sudut pembangunan modal insan di kalangan guru prasekolah, insentif kepada kanak-kanak prasekolah, serta insentif dan pewujudan dasar dalam membangunkan pusat pendidikan awal kanak-kanak. Bagi memastikan aspirasi tersebut tercapai, guru prasekolah sebagai individu yang akan mengajar kanakkanak prasekolah perlu memiliki ciri-ciri guru kompetitif bagi mencapai matlamat tersebut.

Namun begitu, landskap pendidikan seluruh dunia telah berubah berikutan kewujudan Pandemik Covid-19, kerana menyebabkan gangguan terbesar dalam sejarah sistem pendidikan (UN, 2020). Covid-19 yang diisytiharkan oleh Kesatuan Kesihatan Sedunia (WHO) sebagai pandemik global mempunyai kadar mortaliti dan kebolehjangkitan yang sangat tinggi. Malah pengetahuan berkaitan virus tersebut di awal kemunculannya juga sangat terhad (Cucinotta \& Vanelli, 2020). Keadaan ini membawa kepada penutupan pelbagai sektor termasuk pendidikan bagi mengekang penularan Covid19. Penutupan sekolah secara mengejut berikutan pandemik menyebabkan guru-guru buntu dengan tugas mereka, kurang kebolehan untuk mengadaptasi teknologi secara efektif bagi tujuan pembelajaran dan komunikasi, serta tidak bersedia menghadapi cabaran dalam kelas apabila sekolah dibuka (Béteille, Ding, Molina, Pushparatnam, \& Wilichowsk, 2020). Implikasi pandemik menimbulkan persolan, sejauh mana efikasi guru prasekolah menjalankan PdPc pasca pandemik. Oleh itu kajian ini dijalankan bagi mengetahui adakah Pandemik Covid-19 mempunyai pengaruh ke atas efikasi guru untuk menjalankan PdPc di prasekolah.

Efikasi kendiri merupakan kepercayaan tentang keupayaan diri sendiri untuk mengatur dan melaksanakan suatu tindakan yang diperlukan untuk melaksanakan sesuatu (Bandura, 1997). Dalam bidang pendidikan, terdapat tiga kategori dimana kepercayaan efikasi memainkan peranan penting dalam perkembangan dan pencapaian kognitif. Pertama, kepercayaan murid berkenaan efikasi kendiri untuk meningkatkan pembelajaran dan menguasai subjek tertentu, kedua adalah kepercayaan guru keatas efikasi untuk memotivasikan dan menggalakkan pembelajaran dalam kalangan murid, dan ketiga perasaan kolektif efikasi fakulti bahawa sekolah mereka dapat mencapai matlamat akademik yang signifikan (Bandura, 2005). Bakat dan efikasi guru sangat mempengaruhi kreativiti dalam persekitaran pembelajaran. Kepercayaan guru terhadap efikasi arahan mereka, berupaya menentukan cara mereka menstrukturkan aktiviti akademik dalam kelas (Bandura, 1997). 
Pendidikan merupakan suatu proses berterusan. Situasi getir atau masalah luar jangka seperti Pandemik Covid-19 tidak seharusnya menjadi penyebab untuk mengehadkan atau menghentikan sementara proses pendidikan. Bagi memastikan pendidikan prasekolah di negara ini mempunyai kualiti sejajar dengan aspirasi Pelan Pembangunan Pendidikan 2013-2025, maka adalah wajar efikasi kendiri guru dikaji. Hal ini bagi membolehkan efikasi guru semasa adanya pandemik dapat diketahui. Kerana menurut suatu kajian yang dijalankan di negara jiran Filipina dalam daerah Davao mendapati bahawa, Krisis efikasi kendiri mempunyai kolerasi dengan komitmen kerja guru sekolah awam semasa Pandemik Covid-19 (Baloran \& Hernan, 2020).

Tambahan pula garis panduan pengurusan dan pengoperasian sekolah yang dikeluarkan oleh kementerian ternyata membawa kepada perubahan susun atur kelas dan cara PdPc dijalankan, selain menuntut komitmen baharu guru di sekolah. Contohnya untuk prasekolah, rutin circle time atau perbualan pagi tidak dibenarkan dibuat dalam cara asal dimana kanak-kanak duduk dalam kumpulan. Hal ini disebabkan wujud arahan untuk tidak menjalankan aktiviti yang melibatkan perkumpulan (Kementerian Pendidikan Malaysia, 2021). Garis panduan yang dikeluarkan oleh Jabatan Kemajuan Masyarakat untuk Tabika KEMAS pada perkara 3.4.10 dengan jelas mengatakan bahawa sebarang aktiviti berkumpulan adalah tidak dibenarkan (Jabatan Kemajuan Masyarakat, 2020). Keadaan ini sangat bertentangan dengan pendapat Teori pembelajaran John Dewey tentang bagaimana kanakkanak belajar. Menurutnya, pembelajaran pesat kanak-kanak berlaku apabila mereka berinteraksi dengan orang lain, dan bekerja dalam kumpulan secara koperatif dengan rakan-rakan dan orang dewasa. Oleh itu guru sepatutnya mempunyai keyakinan tinggi dalam merancang proses pengalaman pembelajaran kanak-kanak (Mooney, 2013).

Berikutan situasi pandemik yang sedang dihadapi dan SOP pembukaan sekolah, mampukah guru prasekolah mengendali PdPc cara baharu serta menjalankan penilaian IPPK, yang memerlukan guru menilai interaksi, dan kooperasi sesama kanak-kanak dalam kelas prasekolah. Adakah guru resilien dan dapat menjalankan tugas keguruan seperti sebelum Pandemik. Menurut Masten (2014), resilien merupakan suatu sistem dinamik yang mempunyai kebolehan untuk beradaptasi dengan gangguan yang boleh mengganggu fungsi sistem, viabiliti, dan perkembangan. Konsep sistem dinamik ini boleh merujuk kepada individu, keluarga, sekolah, komuniti, organisasi, ekonomi mahupun ekosistem. Dalam konteks kajian ini, gangguan sudah semestinya kewujudan Pandemik Covid-19, yang mana dianggap sebagai gangguan utama yang membawa kepada perubahan pelaksanaan pendidikan secara global (UNESCO, 2020). Salah satu kualiti yang perlu ada pada guru prasekolah adalah, resilien. Hal ini kerana, tahap resilien guru boleh mempengaruhi kesediaan dan keupayaan mereka untuk memupuk resilien pada kanak-kanak prasekolah (Bouillet, Ivanec, \& Miljevic-Ridicki, 2014). Malah menurut Mortimore (1993) pengajaran efektif yang optimum hanya dapat dicapai bilamana wujudnya pengajaran yang efektif. Bray-Clark \& Bates (2003) juga menegaskan bahawa efikasi kendiri guru merupakan pemacu kepada keefektifan guru, dan perlu diberi fokus dalam pembangunan profesional keguruan.

Ternyata masa yang getir ini memerlukan guru mengaplikasikan semua teori dan teknik yang telah dipelajar semasa berada dalam kursus perguruan di maktab mahupun IPT yang menawarkan kursus perguruan. Namun bagaimana pula dengan guru prasekolah yang tidak menerima kursus perguruan khususnya dalam bidang pendidikan awal kanak-kanak. Adakah mereka mempunyai asas pengetahuan yang cukup untuk berhadapan dengan situasi yang baru ini. Program Transformasi Kerajaan yang dilancarkan pada 28 Januari 2010 oleh mantan Perdana Menteri Malaysia Y.A.B Dato' Sri Mohd Najib bin Tun Haji Abdul Razak antara lain bertujuan untuk memberi keutamaan jangka masa pendek bagi memenuhi keperluan rakyat yang dianggap sangat mendesak pada ketika itu. Terdapat enam Bidang Keberhasilan Negara (NKRA) yang mana, Kementerian Kemajuan Luar Bandar dan Wilayah merupakan salah satu daripada enam kementerian peneraju NKRA dan dipertanggungjawabkan dalam bidang memperkasa prasarana luar bandar dan pedalaman (KDN, 2020). Justeru itu, Jabatan Kemajuan Masyarakat di bawah Kementerian Pembangunan Luar Bandar telah bertindak mewujudkan banyak Tabika dan Taska baru khusus untuk membantu kanak-kanak golongan B40 mendapatkan akses pendidikan awal kanak-kanak. Hasilnya, ramai pembantu guru dengan kelayakan SPM dinaiktarafkan menjadi guru tabika, serta berlaku pengambilan guru tabika dan taska daripada pemegang diploma dan ijazah pelbagai bidang selain pendidikan awal kanak-kanak. Sebagai inisiatif menaiktarafkan 
kelayakan profesional guru, Program Kursus Dalam Cuti (KDC) telah dilaksanakan bagi memastikan guru daripada SPM mengikuti pengajian bidang pendidikan awal kanak-kanak peringkat diploma di maktab perguruan dan IPT terpilih. Namun sehingga kini usaha tersebut belum terlaksana sepenuhnya akibat kekangan seperti umur guru senior. Usaha yang sama mula dilaksanakan di kalangan guru daripada kelayakan diploma dan ijazah pelbagai, namun belum terlaksana secara menyeluruh. Pertanyaan dalam pernyataan masalah ini menimbulkan lompang yang membawa kepada asas pembentukan kajian ini. Bagaimanakah efikasi guru prasekolah menjalankan PdPc pasca Pandemik Covid-19, dan adakah latar belakang kelayakan akademik, serta pengalaman mengajar yang berbeza di kalangan guru mempengaruhi efikasi mereka dalam melaksanakan PdPc Pasca Pandemik Covid-19.

Kajian ini bertujuan untuk mengetahui tahap efikasi guru Tabika KEMAS di Ranau menjalankan PdPc Pasca Pandemik Covid-19. Kajian juga mengkaji hubungan kelayakan akademik dan pengalaman mengajar dengan efikasi guru prasekolah Tabika KEMAS menjalankan PdPc pasca Pandemik Covid19, sesuai dengan tuntutan Garis Panduan Pengurusan dan Pengoperasian Sekolah dalam norma baharu. Adakah guru Tabika daripada pelbagai latar akademik, dan tempoh mengajar mampu beradaptasi dengan suasana baru dalam norma pembelajaran cara baharu.

Terdapat tiga persoalan utama yang terbit daripada objektif kajian

i. Adakah tahap efikasi kendiri guru prasekolah Tabika KEMAS di Ranau untuk menjalankan PdPc semasa Pasca Pandemik Covid-19 berada pada tahap rendah, sederhana, atau tinggi?

ii. Adakah kelayakan akademik mempunyai hubungan dengan tahap efikasi kendiri guru Prasekolah Tabika KEMAS Daerah Ranau dalam menjalankan PdPc Pasca Pandemik Covid19 ?

iii. Adakah pengalaman mengajar mempunyai hubungan dengan tahap efikasi kendiri guru Prasekolah Tabika KEMAS Daerah Ranau dalam menjalankan PdPc Pasca Pandemik Covid$19 . ?$

\section{Hipotesis kajian}

H1: Tidak terdapat hubungan yang signifikan efikasi kendiri guru Tabika KEMAS di Ranau menjalankan PdPc pasca Pandemik Covid-19 berdasarkan kelayakan akademik.

H2: Tidak terdapat hubungan signifikan efikasi kendiri guru Tabika KEMAS di Ranau menjalankan PdPc pasca Pandemik Covid-19 berdasarkan pengalaman mengajar.

Sistem pendidikan di Malaysia belum bersedia menjalankan sepenuhnya pembelajaran secara virtual. Ini kerana masih banyak kawasan yang tidak mempunyai akses internet yang baik dan kondusif untuk tujuan pembelajaran dalam talian (Salleh \& Abdullah, 2015). Justeru pembelajaran seperti biasa di kelas masih menjadi pilihan utama. Dengan adanya kajian ini, efikasi kendiri guru dapat difahami dengan lebih jelas. Adakah adaptasi positif berlaku dalam bidang pendidikan prasekolah semasa norma baharu pembelajaran. Kerana efikasi kendiri guru memberi pengaruh yang kuat keatas prestasi kerja guru (Dasan \& Md Nawi, 2020).

Bidang pendidikan memerlukan pengurusan dan perancangan strategik untuk mencapai aspirasi PPPM 2013-2025. Justeru dalam menghadapi ketidaktentuan dunia, kebolehan untuk bertindak balas dengan cepat dengan perubahan semasa, dan menguatkuasakan strategi organisasi dengan betul adalah sangat penting (Hill, Jones, \& Schilling, 2015). Hasil kajian ini akan memberi gambaran berkenaan efikasi guru dalam melaksana PdPc norma baharu, dimana berlaku limitasi aktiviti akibat terikat dengan garis panduan pengurusan dan pengoperasian sekolah. Efikasi guru, khususnya di kalangan guru yang berlatarbelakangkan bidang pendidikan awal kanak-kanak dan sebaliknya. Hasil ini dapat menjadi rujukan pengurusan dan pembangunan bidang pendidikan awal kanak-kanak seterusnya dijadikan asas kepada kajian tindakan seperti pembangunan kurikulum khusus semasa penjarakan sosial perlu diaplikasikan. Dengan memahami efikasi guru, bidang pendidikan khususnya pendidikan prasekolah akan lebih bersedia dengan kewujudan endemik, pandemik, mahupun sebarang faktor yang membawa kepada perubahan pelaksanaan PdPc pada masa hadapan. Walaupun vaksin Covid-19 sudah berjaya 
dihasilkan namun kemajuan teknologi dan bidang virulogi yang ada sekarang, belum cukup untuk dunia bersedia dengan pandemik viral seterusnya (Adamson, Chibale, Goss, Jaspars, Newman \& Dorrinton, 2021). Malah PPPM 2013-2025 yang bakal dikaji semula, dapat mengutarakan isu ini sebagai perkara yang perlu diberi perhatian dalam membangunkan pelan pembangunan pendidikan seterusnya yang lebih resisten dengan masalah seumpama ini.

Kajian ini merupakan kajian terhadap efikasi guru prasekolah. Namun dalam kajian yang dijalankan, guru prasekolah hanya tertumpu kepada guru prasekolah Tabika KEMAS di bawah Jabatan KEMAS Daerah Ranau. Oleh itu data yang diperoleh mungkin berlainan dengan data daripada Tabika KEMAS lain seperti yang ada kawasan bandar, atau juga prasekolah agensi swasta yang sememangnya mempunyai perbezaan dengan Tabika KEMAS di Ranau. Jangka masa atau timeframe pasca pandemik pula adalah terhad kepada PdPc bersemuka yang mula dilaksanakan pada Julai 2020 hingga Mei 2021.

Kelayakan akademik yang dimaksudkan dalam tajuk ini, merujuk kepada tahap pendidikan guru iaitu sama ada PMR/SPM, STPM, Diploma pelbagai bidang, Diploma Pendidikan, Ijazah pelbagai bidang dan Ijazah pendidikan. Pengalaman mengajar merujuk kepada pengalaman guru mengajar di Tabika KEMAS. Efikasi kendiri guru merujuk kepada keyakinan guru Tabika KEMAS menjalankan PdPc di kelas Tabika dari segi penglibatan murid, efikasi dalam strategi arahan, dan efikasi dalam pengurusan kelas. Jangka masa Pasca Covid-19 yang dimaksudkan adalah bermula pada Julai 2020 sehingga Mei 2021. Dalam tempoh ini, pelaksanaan PdPc di Tabika KEMAS dijalankan mengikut Garis Panduan Pengoperasian Tabika dan Taska, dan majoriti guru tabika belum mendapat vaksinasi Covid-19.

\section{Sorotan Literatur}

Menurut Tschannen-Moran dan Hoy (2001), efikasi guru merupakan faktor utama yang mempengaruhi keberhasilan pendidikan seperti kegigihan, semangat, komitmen dan tingkah laku terarah guru serta keberhasilan murid seperti pencapaian, motivasi dan kepercayaan efikasi diri. Bagi memastikan efikasi keguruan dikaji secara menyeluruh, Ohio State Teacher Efficacy Scale (OSTES) atau kini lebih dikenali sebagai Teacher Sense of Efficacy Scale (TSES) telah dibangunkan berdasarkan kepada Teori SosioKognitif Bandura (1997). Sehingga kini instrumen yang dibangunkan oleh Tschannen-Moran dan Hoy (2001) merupakan antara instrumen yang banyak digunakan dalam mengukur tahap efikasi guru dalam tiga dimensi utama iaitu strategi arahan atau pengajaran, penglibatan murid, dan pengurusan kelas.

Kajian Toran (2017) berkaitan efikasi kendiri guru prasekolah yang menggunakan instrumen TSES telah dapat melihat efikasi guru prasekolah berdasarkan beberapa variabel berkaitan pembangunan profesional yang dikaji. Toran (2017) mendapati latar belakang akademik iaitu berkaitan dengan jenis program guru bergraduasi mempengaruhi tahap efikasi secara signifikan. Jenis kawasan tempat guru bertugas, sama ada kampung atau dalam lingkungan majlis perbandaran juga secara signifikan menyumbang kepada efikasi guru dalam dimensi pengurusan murid dan strategi pengajaran. Hubungan antara pengalaman mengajar dengan efikasi mendapati, semakin lama pengalaman mengajar guru, maka semakin rendah tahap efikasi mereka menjalankan PdPc. Kajian lain berkaitan efikasi guru prasekolah dalam pengurusan kelas juga mendapati, efikasi guru berkurangan apabila pengalaman mengajar bertambah. Keadaan tersebut dikaitkan dengan burnout di kalangan guru (Toran \& Gencgel, 2016). Dapatan tersebut juga sama dengan kajian efikasi guru prasekolah di kawasan luar bandar (Infurna, Riter, \& Schultz, 2018). Didapati bahawa pengalaman mengajar dan efikasi menunjukkan signifikan negatif. Semakin tinggi pengalaman maka semakin rendah efikasi kendiri guru untuk mengajar dan meningkatkan pencapaian kanak-kanak di kelas prasekolah. Namun begitu, dapatan ini adalah berlainan dengan kajian efikasi guru prasekolah yang dijalankan oleh Mulok dan Yunus (2020). Didapati bahawa, pengalaman mengajar dan kelayakan akademik yang berbeza tidak menentukan tahap efikasi guru prasekolah menjalankan PdPc.

Hasil kajian Dasan dan Md Nawi (2020) mendapati, efikasi kendiri adalah faktor utama yang membawa kepada prestasi kerja cemerlang di kalangan guru. Justeru mereka mempunyai kompetensi tinggi dengan tuntutan semasa pihak sekolah. Pengkaji juga mendapati strategi pengajaran merupakan 
indikator utama kepada prestasi kerja, berbanding dimensi penglibatan murid dan pengurusan kelas. Ini kerana guru yang berkemahiran dalam bidang pengkhususannya mempunyai kebolehan merancang pengajaran yang mudah murid fahami.

Dalam bidang pendidikan inklusif kelas prasekolah, didapati bahawa guru prasekolah yang mempunyai efikasi kendiri tinggi, cenderung menerima kehadiran murid berkeperluan khas dalam kelas mereka. Efikasi paling tinggi adalah dari segi pengajaran, seterusnya diikuti oleh kerjasama dan tingkah laku. Efikasi yang rendah untuk pengurusan tingkah laku murid, adalah disebabkan kesukaran mengurus tingkah laku akibat kekurangan pengalaman dan pengetahuan. Efikasi kendiri juga tidak dipengaruhi secara signifikan oleh jantina dan pengalaman mengajar. Justeru ia bukanlah indikator yang dapat menentukan efikasi kendiri guru (Jongkulin, Talip, \& Taat, 2019). Hasil yang sama juga diperolehi oleh Woodcock dan Jones (2020). Didapati bahawa, semakin tinggi tahap efikasi guru maka semakin cenderung mereka mempunyai kesediaan peribadi dan profesionalisme untuk mengajar dalam kelas inklusif.

Kajian Khairani (2016) berkenaan efikasi kendiri guru pelatih menjalankan pengajaran mendapati bahawa, guru pelatih mempunyai efikasi pengajaran yang tinggi khususnya dalam dimensi pengurusan kelas. Mereka yakin dengan kebolehan untuk mengawal peraturan, mengawal tingkah laku murid, serta menenangkan murid yang menunjukkan tingkah laku disruptif. Efikasi kedua tertinggi adalah daripada dimensi strategi pengajaran, dan diikuti penglibatan murid. Berbeza dengan guru yang masih baru dalam perkhidmatan, didapati bahawa walaupun efikasi pengajaran tinggi namun dimensi penglibatan murid, dan pengurusan kelas adalah bahagian yang kurang diyakini (Dimitrios A \& Koustelios, 2016).

Daripada contoh kajian lepas tersebut, dapat dilihat bahawa guru yang berkemahiran dan berpengetahuan khususnya dalam bidang mereka, mempunyai efikasi yang tinggi dalam melaksanakan tugas keguruan. Ini juga dapat disokong oleh kajian Yoo (2016) yang mendapati pembangunan profesionalisme guru mempunyai kesan positif ke atas efikasi guru.

Dalam era Pasca Covid-19, guru merupakan pekerjaan yang vurnebal dengan jangkitan. Ini kerana kebarangkalian mendapat jangkitan lebih banyak kerana perlu berjumpa dengan ramai orang. Laporan Beng, Wardle dan Collie (2020) berkenaan respons guru terhadap pembukaan sekolah menimbulkan reaksi pelbagai. Laporan ini dilakukan di England bagi mengetahui respons pembukaan sekolah pada Jun 2020. Pada waktu ini, vaksin Covid-19 belum ditemukan. Majoriti menganggap pembukaan sekolah tidak wajar kerana guru tidak berasa selamat untuk menjalankan PdPc. Tiga perempat daripada guru menganggap, penjarakan sosial di sekolah tidak akan efektif. Kebanyakan guru tidak yakin bahawa langkah keselamatan di sekolah akan dipatuhi. Guru juga didapati hanya bersetuju kembali ke sekolah sekiranya langkah keselamatan yang tinggi dibuat, seperti penjarakan sosial efektif, kekerapan mencuci tangan, pembersihan menyeluruh, sistem pengesanan dan pengasingan wujud (Beng, Wardle, \& Collie, 2020). Jika dilihat daripada sudut efikasi Bandura (1997), guru ini tidak akan mempunyai efikasi kendiri untuk menjalankan PdPc. Jika dikaitkan semula dengan Teori Herzberg, terdapat gangguan di tempat kerja yang membuatkan mereka tidak dapat menunjukkan kualiti kerja seperti yang sepatutnya.

Populasi bagi kajian ini adalah di kalangan guru Tabika KEMAS atau juga dikenali sebagai Pendidik Masyarakat Tabika KEMAS di bawah Jabatan KEMAS Daerah Ranau. Kanak-kanak di Tabika berada dalam lingkungan umur antara empat hingga enam tahun. Pendidik Masyarakat Tabika KEMAS yang dikaji bertugas sebagai guru Tabika KEMAS di kawasan Dun N36 Kundasang, N37 Karanaan, dan N38 Paginatan dalam parlimen P179 Ranau. Sampel (N=74) ditentukan melalui formula penentuan sampel Krejcie-Morgan.

Kajian ini dijalankan dengan menggunakan Instrumen Teacher's Sense of Efficacy Scale (TSES). TSES mengandungi senarai soal selidik yang menggunakan skala likert dan kajian ini menggunakan TSES versi short form dengan 12 item soalan. Tiga dimensi utama efikasi yang dikaji melibatkan efikasi dalam penglibatan murid, efikasi dalam strategi arahan, dan efikasi dalam pengurusan kelas (Tschannen-Moran \& Hoy, 2001). 


\section{Hasil Kajian}

\section{Maklumat demografi}

Semasa kajian dijalankan, beberapa guru telah pencen menyebabkan saiz populasi dan sampel berubah daripada perancangan awal. Dengan menggunakan kiraan sampel mengikut formula Krejcie-Morgan, populasi 91 adalah bersamaan dengan 74 sampel atau responden, iaitu guru Tabika KEMAS di Daerah Ranau, Sabah. Maklumat demografi dapat dilihat secara terperinci seperti dalam jadual 1.

Jadual 1: Latar belakang demografi sampel

\begin{tabular}{llcc}
\hline \multicolumn{1}{c}{ Item } & \multicolumn{1}{c}{ Butiran } & Kekerapan & $\begin{array}{c}\text { Peratusan } \\
(\boldsymbol{\%})\end{array}$ \\
\hline Jantina & Lelaki & 3 & 4.1 \\
Umur & Perempuan & 71 & 95.9 \\
& $25-29$ & 6 & 8.1 \\
& $30-34$ & 27 & 36.5 \\
& $35-39$ & 18 & 24.3 \\
& $40-44$ & 8 & 10.8 \\
& $45-49$ & 3 & 4.1 \\
Kelayakan & $50-54$ & 1 & 1.4 \\
akademik & $55-59$ & 11 & 14.9 \\
& PMR/SPM & 10 & 14.9 \\
& STPM & 3 & 4.1 \\
& Diploma pelbagai & 13 & 17.6 \\
& Diploma pendidikan awal kanak- & 38 & 51.4 \\
& kanak & & \\
& Ijazah pelbagai & 7 & 9.5 \\
Tempoh bertugas & 2 & 2.7 \\
& Ijazah pendidikan awal kanak- & & \\
& kanak & 11 & 14.9 \\
& Kurang 5 tahun & 13 & 17.6 \\
& 5 - 9 tahun & 34 & 45.9 \\
& 10 - 14 tahun & 2 & 2.7 \\
& 15 - 19 tahun & 1 & 1.4 \\
& 20 -24 tahun & 3 & 4.1 \\
& 25 - 29 tahun & 10 & 13.5 \\
& 30 tahun dan ke atas & &
\end{tabular}

Kajian ini melibatkan tiga (4.1\%) guru lelaki, dan 71 (95.9\%) guru perempuan. Bilangan sampel guru perempuan lebih ramai kerana, hanya terdapat tiga guru lelaki di Tabika KEMAS Daerah Ranau. Guru yang paling ramai terlibat dalam kajian berumur dalam lingkungan 30 - 34 tahun, iaitu seramai 27 responden $(36.5 \%)$, diikuti umur 35 - 39 tahun seramai 18 orang (24.3\%). Responden paling sedikit iaitu seramai satu orang (1.4\%) berada dalam lingkungan umur 50 - 54 tahun, diikuti responden dalam lingkungan umur $45-49$ tahun iaitu seramai tiga orang (4.1\%). Kekerapan tertinggi bagi tempoh bertugas responden adalah dalam lingkungan 10 - 14 tahun iaitu seramai 34 orang (45.9\%), ini diikuti tempoh bertugas dalam lingkungan lima hingga sembilan tahun iaitu bersamaan 13 orang (17.6\%). Kekerapan pengalaman bekerja atau tempoh bertugas paling rendah adalah dalam lingkungan 20-24 tahun (1.4\%), ini diikuti dengan tempoh bertugas dalam lingkungan 25-29 tahun seramai tiga orang $(4.1 \%)$. Dari segi premis kelas tabika pula, 43 buah tabika (58.1\%) merupakan bangunan yang tiada perkongsian penggunaan dengan mana-mana pihak. iaitu sama ada bangunan milik KEMAS atau disewa khas. Manakala $31(41.9 \%)$ buah tabika lagi berada dalam premis balai raya atau dewan kampung. 


\section{Tahap efikasi kendiri guru}

Tahap efikasi guru prasekolah menjalankan PDPC pasca Covid-19 diukur melalui analisis deskriptif. Skor min dinilai berdasarkan jadual interpretasi skor min seperti jadual 2 berikut.

Jadual 2 : Jadual interpretasi skor min

\begin{tabular}{cc}
\hline Skor min & Intrepetasi min \\
\hline $4.01-5.00$ & Tinggi \\
$3.01-4.00$ & Sederhana tinggi \\
$2.01-3.00$ & Sederhana rendah \\
$1.00-2.00$ & Rendah \\
\hline
\end{tabular}

Sumber: Nunnally dan Bernstein (1994)

Secara keseluruhan tahap efikasi kendiri guru berada pada tahap sederhana tinggi. Ini dapat dibuktikan dengan skor min=3.69, $\mathrm{SD}=0.59$. Dengan merujuk kepada jadual intrepetasi skala min, nilai ini berada pada tahap sederhana tinggi. Ini bermaksud, pada awal pasca pandemik Covid-19, guru pendidikan awal kanak-kanak yang mengajar kanak-kanak berusia empat hingga enam tahun di Tabika KEMAS daerah Ranau menunjukkan mereka mempunyai tahap efikasi sederhana tinggi dalam melaksana PdPC di kelas.

\section{Tahap efikasi kendiri guru mengikut dimensi efikasi}

Tahap efikasi dalam kajian ini terbahagi kepada tiga dimensi iaitu, efikasi dalam penglibatan murid, efikasi dalam strategi arahan, dan efikasi dalam pengurusan kelas.

Jadual 3: Analisis SPSS tahap efikasi secara keseluruhan

\begin{tabular}{llllll}
\hline & N & Minimum & Maximum & Mean & Std. Deviation \\
\hline EFIKASI & 74 & 2.67 & 5.00 & 3.6926 & .59567 \\
Valid N (listwise) & 74 & & & & \\
\hline
\end{tabular}

Jadual 4: Analisis SPSS tahap efikasi mengikut dimensi efikasi

\begin{tabular}{llllll}
\hline Dimensi & N & Minimum & Maximum & Mean & Std. Deviation \\
\hline PENGLIBATAN & 74 & 2.50 & 5.00 & 3.6723 & .60665 \\
ARAHAN & 74 & 2.75 & 5.00 & 3.7027 & .58473 \\
PENGURUSAN & 74 & 2.50 & 5.00 & 3.7027 & .66682 \\
Valid N (listwise) & 74 & & & & \\
\hline
\end{tabular}

Jika dinilai dari segi dimensi efikasi, walaupun semua dimensi berada pada tahap sederhana tinggi namun didapati bahawa efikasi dalam strategi arahan dan pengurusan kelas menunjukkan nilai yang sama dan lebih tinggi berbanding efikasi guru dalam penglibatan murid. Ini dapat dilihat dalam rajah 4, dimana min efikasi dalam strategi arahan bersamaan $\mathrm{M}=3.70, \mathrm{SD}=0.58$, manakala efikasi dalam pengurusan kelas bersamaan $\mathrm{M}=3.70, \mathrm{SD}=0.66$. Efikasi dalam penglibatan lebih rendah walaupun masih berada dalam tahap tinggi iaitu $\mathrm{M}=3.67, \mathrm{SD}=0.60$.

Jadual 5 : Analisis SPSS berkenaan tahap efikasi mengikut dimensi

\begin{tabular}{llll}
\hline Dimensi & No. item & Mean & Std.Deviation \\
\hline \multirow{3}{*}{ Efikasi dalam penglibatan murid } & b2 & 3.61 & .773 \\
& b4 & 3.78 & .707 \\
Efikasi dalam strategi arahan & b7 & 3.77 & .713 \\
& b11 & 3.53 & .667 \\
\hline
\end{tabular}


DOI: https://doi.org/10.47405/mjssh.v6i10.1105

\begin{tabular}{llll}
\hline & b9 & 3.58 & .722 \\
& b10 & 3.78 & .625 \\
& b12 & 3.65 & .671 \\
Efikasi dalam pengurusan kelas & b1 & 3.70 & .806 \\
& b3 & 3.69 & .757 \\
& b6 & 3.76 & .791 \\
& b8 & 3.66 & .688 \\
\hline
\end{tabular}

Penilaian terperinci tahap efikasi mengikut setiap item dapat dilihat dalam jadual 5. Item b5 (sejauh mana anda dapat membina soalan yang bagus untuk murid) yang merupakan item dimensi efikasi dari segi arahan mencatatkan min tertinggi iaitu $\mathrm{M}=3.80, \mathrm{SD}=0.70$. Ini bermaksud guru mempunyai tahap keyakinan sederhana tinggi dari segi pembinaan soalan yang bagus untuk murid walaupun berada dalam PdPC pasca pandemik. Guru menunjukkan keyakinan paling kurang dalam item b11 iaitu untuk membimbing keluarga membantu kanak-kanak mereka berjaya di sekolah. Ini dibuktikan dengan nilai $\mathrm{M}=3.53, \mathrm{SD}=0.66$.

Walaupun efikasi dalam penglibatan murid menunjukkan tahap terendah berbanding dimensi lain, namun terdapat item yang mencatatkan min lebih tinggi berbanding min item pada dimensi efikasi pengurusan kelas. Item b4 (sejauh mana anda dapat membantu murid untuk menghargai pembelajaran) mencatatkan $\mathrm{M}=3.78, \mathrm{SD}=0.70$, bermaksud keyakinan guru sangat tinggi dalam membantu murid menghargai pembelajaran semasa di kelas. Dari segi efikasi dalam strategi arahan, guru paling kurang keyakinan dalam item b9 (Sejauh mana anda dapat menggunakan kepelbagaian dalam strategi penilaian). Ini ditunjukkan dengan nilai $\mathrm{M}=3.58, \mathrm{SD}=0.72$. Nilai ini lebih kecil daripada min yang ditunjukkan daripada semua item dimensi efikasi pengurusan kelas. Bermaksud, guru kurang berkeyakinan dari segi penggunaan kepelbagaian dalam strategi penilaian. Ini mungkin disebabkan oleh keperluan mematuhi Standard Pengoperasian Semula Tabika yang telah ditetapkan oleh kementerian pelajaran, dimana penjarakan sosial sangat dititikberatkan.

Dalam dimensi efikasi pengurusan kelas, item b6 (sebanyak mana anda dapat membuatkan kanakkanak mematuhi peraturan kelas) menunjukkan nilai paling tinggi iaitu $\mathrm{M}=3.76, \mathrm{SD}=0.79$. Bermaksud daripada semua item dalam pengurusan kelas, guru paling yakin dalam membuatkan kanak-kanak mematuhi peraturan kelas. Namun nilai item dalam dimensi ini adalah paling rendah pada item $\mathrm{b} 8$ (sebaik mana anda dapat membina sistem pengurusan kelas dengan setiap murid) iaitu dengan catatan $\mathrm{M}=3.66, \mathrm{SD}=0.68$. Bermaksud guru kurang yakin membina sistem pengurusan kelas dengan setiap kumpulan murid. Ini mungkin disebabkan guru masih terikat dengan manual pengoperasian tabika yang menghalang aktiviti berkumpulan dilaksanakan.

Secara keseluruhannya, tahap efikasi guru berada pada tahap sederhana tinggi. Namun tahap efikasi guru adalah berbeza mengikut dimensi. Walaupun setiap dimensi berada pada tahap sederhana tinggi, namun guru mempunyai tahap efikasi atau keyakinan lebih tinggi dalam dimensi arahan dan pengurusan kelas. Guru paling kurang yakin tentang tahap penglibatan kanak-kanak dalam PdPC di kelas.

\section{Analisis inferensi}

Analisis inferensi dilakukan untuk menjawab persoalan kedua kajian, berkaitan hubungan antara tahap efikasi dengan kelayakan akademik dan pengalaman bekerja sebagai guru di Tabika KEMAS. Hubungan mengikut dimensi atau domain efikasi juga akan diperincikan. Analisis inferensi dijalankan dengan menggunakan Korelasi Pearson. Penggunaan kaedah parametrik ini ditentukan selepas melakukan pengujian normaliti data. Dengan merujuk kepada nilai Skewness, data tertabur secara normal iaitu berada dalam lingkungan nilai normal $(-1.96-+1.96)$. Tahap kekuatan hubungan antara pemboleh ubah mengikut nilai pekali korelasi dapat dirujuk dalam jadual 6. 
DOI: https://doi.org/10.47405/mjssh.v6i10.1105

Jadual 6: Tahap hubungan mengikut nilai pekali korelasi r

\begin{tabular}{cc}
\hline Nilai $\mathbf{r}$ & Tahap hubungan \\
\hline $0.81-1.00$ & Sangat kuat \\
$0.61-0.80$ & kuat \\
$0.41-0.60$ & Sederhana kuat \\
$0.21-0.40$ & Lemah \\
$0.01-0.20$ & Sangat lemah \\
\hline
\end{tabular}

Sumber: Cohen, Manion, \& Morrison (2018)

\section{Hubungan kelayakan akademik dengan tahap efikasi guru}

Jadual 7 menerangkan hubungan akademik dengan efikasi guru. Hasil analisis menunjukkan hubungan antara akademik dengan tahap efikasi merupakan satu hubungan negatif yang sangat lemah dan tidak signifikan, dimana nilai $\mathrm{r}=-.161, \mathrm{k}>0.05$. Bermaksud kelayakan akademik tidak menentukan tahap efikasi guru. Oleh itu $\mathrm{H} 1$ yang mengatakan tidak terdapat hubungan yang signifikan efikasi kendiri guru Tabika KEMAS di Ranau menjalankan PdPc pasca Pandemik Covid-19 berdasarkan kelayakan akademik adalah diterima.

Jadual 7 : Analisis Korelasi Pearson kelayakan akademik dengan efikasi kendiri

\begin{tabular}{llcc}
\hline & & AKADEMIK & EFIKASI \\
\hline \multirow{3}{*}{ AKADEMIK } & Pearson Correlation & 1 & -.161 \\
& Sig. (2-tailed) & & .170 \\
& $\mathrm{~N}$ & 74 & 74 \\
\multirow{2}{*}{ EFIKASI } & Pearson Correlation & -.161 & 1 \\
& Sig. (2-tailed) & .170 & 74 \\
\hline
\end{tabular}

\section{Hubungan pengalaman mengajar dengan tahap efikasi guru}

Keadaan ini sedikit berlainan dengan hubungan antara pengalaman akademik dengan tahap efikasi guru seperti yang terdapat dalam jadual 8. Hasil analisis menunjukkan hubungan antara pengalaman mengajar dengan tahap efikasi merupakan satu hubungan positif yang lemah tetapi tidak signifikan. Ini ditunjukkan dengan nilai $\mathrm{r}=.206, \mathrm{k}<.05$. Oleh itu $\mathrm{H} 2$ yang mengatakan tidak terdapat hubungan signifikan efikasi kendiri guru Tabika KEMAS di Ranau menjalankan PdPc pasca Pandemik Covid-19 berdasarkan pengalaman mengajar adalah diterima.

Jadual 8 : Analisis Korelasi Pearson pengalaman mengajar dengan efikasi kendiri

\begin{tabular}{llll}
\hline & & PENGALAMAN & EFIKASI \\
\hline \multirow{3}{*}{ PENGALAMAN } & Pearson Correlation & 1 & .206 \\
& Sig. (2-tailed) & & .078 \\
& $\mathrm{~N}$ & 74 & 74 \\
\multirow{2}{*}{ EFIKASI } & Pearson Correlation & .206 & 1 \\
& Sig. (2-tailed) & .078 & \\
& $\mathrm{~N}$ & 74 & 74 \\
\hline
\end{tabular}

\section{Hubungan kelayakan akademik dengan tahap efikasi mengikut dimensi}

Jadual 9 menerangkan hubungan kelayakan akademik guru dengan efikasi dalam dimensi penglibatan murid. Analisis menunjukkan hubungan antara kelayakan akademik dengan dimensi penglibatan 
murid merupakan satu hubungan negatif yang sangat lemah dan tidak signifikan, dimana nilai $\mathrm{r}=-.138$, $\mathrm{k}>0.05$. Bermaksud kelayakan akademik tidak menentukan tahap efikasi guru dalam dimensi penglibatan murid semasa PdPc.

Jadual 9: Analisis Korelasi Pearson hubungan kelayakan akademik dengan efikasi penglibatan murid

\begin{tabular}{llll}
\hline & & Kelayakan Akademik & Penglibatan Murid \\
\hline \multirow{3}{*}{ Kelayakan Akademik } & Pearson Correlation & 1 & -.138 \\
& Sig. (2-tailed) & & .243 \\
& N & 74 & 74 \\
\multirow{2}{*}{ Penglibatan Murid } & Pearson Correlation & -.138 & 1 \\
& Sig. (2-tailed) & .243 & \\
& $\mathrm{~N}$ & 74 & 74 \\
\hline
\end{tabular}

Jadual 10 menerangkan hubungan kelayakan akademik guru dengan efikasi dalam dimensi arahan guru. Analisis menunjukkan hubungan antara kelayakan akademik dengan dimensi arahan guru merupakan satu hubungan negatif yang sangat lemah dan tidak signifikan, dimana nilai $\mathrm{r}=-.124$, $\mathrm{k}>0.05$. Bermaksud kelayakan akademik guru tidak menentukan tahap efikasi kendiri mereka dari segi dimensi arahan guru semasa PdPc.

Jadual 10 : Analisis Korelasi Pearson hubungan kelayakan akademik dengan Efikasi arahan guru

\begin{tabular}{llcc}
\hline & & Kelayakan Akademik & Arahan Guru \\
\hline \multirow{3}{*}{ Kelayakan Akademik } & Pearson Correlation & 1 & -.124 \\
& Sig. (2-tailed) & & .292 \\
& N & 74 & 74 \\
\multirow{5}{*}{ Arahan Guru } & Pearson Correlation & -.124 & 1 \\
& Sig. (2-tailed) & .292 & 74 \\
\hline
\end{tabular}

Jadual 11 menunjukkan hubungan kelayakan akademik guru dengan efikasi dalam dimensi pengurusan kelas. Analisis menunjukkan adanya hubungan negatif yang sangat lemah dan tidak signifikan, dimana nilai $\mathrm{r}=-.198, \mathrm{k}>0.05$. Ini menunjukkan kelayakan akademik guru tidak menentukan tahap efikasi kendiri guru dalam dimensi pengurusan kelas. Bermaksud kelayakan akademik tidak menentukan sejauh mana efikasi guru mengurus kelas semasa PdPc pasca Pandemik Covid-19.

Jadual 11 : Analisis Korelasi Pearson hubungan kelayakan akademik dengan efikasi pengurusan kelas

\begin{tabular}{llcc}
\hline & & Kelayakan Akademik & Pengurusan kelas \\
\hline \multirow{3}{*}{ Kelayakan Akademik } & Pearson Correlation & 1 & -.198 \\
& Sig. (2-tailed) & & .090 \\
& $\mathrm{~N}$ & 74 & 74 \\
\multirow{5}{*}{ Pengurusan kelas } & Pearson Correlation & -.198 & 1 \\
& Sig. (2-tailed) & .090 & 74 \\
\hline
\end{tabular}

\section{Hubungan pengalaman mengajar dengan tahap efikasi mengikut dimensi}

Jadual 12 menunjukkan hubungan pengalaman mengajar guru dengan efikasi dalam dimensi penglibatan murid. Analisis menunjukkan adanya hubungan positif yang lemah dan tidak signifikan, dimana nilai $\mathrm{r}=.214, \mathrm{k}>0.05$. Ini menunjukkan pengalaman mengajar guru tidak menentukan tahap 
DOI: https://doi.org/10.47405/mjssh.v6i10.1105

efikasi dalam dimensi penglibatan murid, iaitu penglibatan kanak-kanak di kelas prasekolah semasa PdPc pasca Pandemik Covid-19.

Jadual 12 : Analisis Korelasi Pearson hubungan pengalaman mengajar dengan efikasi penglibatan murid

\begin{tabular}{llll}
\hline & & Tempoh Bertugas & Penglibatan Murid \\
\hline \multirow{3}{*}{ Tempoh Bertugas } & Pearson Correlation & 1 & .214 \\
& Sig. (2-tailed) & & .067 \\
& N & 74 & 74 \\
& Pearson Correlation & .214 & 1 \\
Penglibatan Murid & Sig. (2-tailed) & .067 & 74 \\
& $\mathrm{~N}$ & 74 & 74 \\
\hline
\end{tabular}

Jadual 13 menunjukkan hubungan pengalaman mengajar guru dengan efikasi dalam dimensi penglibatan murid. Analisis menunjukkan adanya hubungan positif yang sangat lemah dan tidak signifikan, dimana nilai $\mathrm{r}=.214, \mathrm{k}>0.05$. Bermaksud, pengalaman mengajar guru tidak menentukan tahap efikasi dalam dimensi arahan guru. Ini menunjukkan semasa PdPc pasca Pandemik Covid-19, pengalaman mengajar guru tidak menentukan efikasi kendiri mereka dalam memberi arahan yang berkesan untuk kanak-kanak prasekolah.

Jadual 13 : Analisis Korelasi Pearson hubungan pengalaman mengajar dengan efikasi arahan guru

\begin{tabular}{llcc}
\hline & & Tempoh Bertugas & Arahan Guru \\
\hline \multirow{3}{*}{ Tempoh_Bertugas } & Pearson Correlation & 1 & .139 \\
& Sig. (2-tailed) & & .239 \\
& $\mathrm{~N}$ & 74 & 74 \\
\multirow{2}{*}{ Arahan_Guru } & Pearson Correlation & .139 & 1 \\
& Sig. (2-tailed) & .239 & \\
& $\mathrm{~N}$ & 74 & 74 \\
\hline
\end{tabular}

Jadual 14 menunjukkan hubungan pengalaman mengajar guru dengan efikasi dalam dimensi pengurusan kelas. Hasil analisis korelasi menunjukkan hubungan antara pengalaman mengajar dan efikasi pengurusan kelas merupakan satu hubungan positif yang lemah tetapi signifikan, dimana nilai $\mathrm{r}=.236, \mathrm{k}<0.05$. Keputusan ini menjelaskan bahawa apabila pengalaman mengajar tinggi, maka efikasi guru dalam dimensi pengurusan kelas juga dilaporkan tinggi. Ini menunjukkan semasa PdPc pasca Pandemik Covid-19, pengalaman mengajar guru menentukan efikasi kendiri mereka dalam pengurusan kelas.

Jadual 14 : Analisis Korelasi Pearson pengalaman mengajar dengan efikasi pengurusan kelas

\begin{tabular}{llcc}
\hline & & Tempoh Bertugas & Pengurusan kelas \\
\hline \multirow{3}{*}{ Tempoh Bertugas } & Pearson Correlation & 1 & $.236^{*}$ \\
& Sig. (2-tailed) & & .043 \\
& $\mathrm{~N}$ & 74 & 74 \\
\multirow{2}{*}{ Pengurusan kelas } & Pearson Correlation & $.236^{*}$ & 1 \\
& Sig. (2-tailed) & .043 & 74 \\
\hline
\end{tabular}

*. Correlation is significant at the 0.05 level (2-tailed)

\section{Perbincangan dan Kesimpulan}

Hasil analisis mendapati tahap efikasi guru melaksana PdPc di kelas prasekolah semasa pasca pandemik Covid-19 berada pada tahap sederhana tinggi. Hal ini mungkin disebabkan adanya 
pandemik Covid-19 yang merbahaya dan sukar diramal. Pandemik ini telah bertindak sebagai faktor hygene yang menyumbang kepada efikasi yang sederhana tinggi rendah guru tabika (Gitman et al., 2018). Guru tabika juga mungkin mempunyai persepsi sama dengan dapatan Beng, Wardle dan Collie (2020). Didapati bahawa, guru sememangnya risau dengan keselamatan diri semasa melaksana pengajaran secara bersemuka. Ada juga yang tidak yakin sekiranya SOP akan benar-benar dipatuhi, malah ramai yang akan menjalankan PdPc sekiranya langkah keselamatan tinggi diambil.

Garis Panduan Pengoperasian Tabika dan Taska yang dikeluarkan oleh Jabatan Kemajuan Masyarakat juga tidak membenarkan pelaksanaan aktiviti secara berkumpulan di kelas tabika. Malah, bagi mengawal penularan pandemik, penjarakan sosial menyebabkan kontak guru dengan juga perlu dikurangkan. Ini menyebabkan aktiviti yang biasa dilaksanakan sebelum pandemik, tidak dapat dijalankan. Kaedah pembelajaran dalam norma baharu ini bertentangan dengan Teori scaffolding Vygotsky, dimana suasana belajar cenderung kepada interaksi antara guru dengan murid atau murid dengan murid (Levine \& Munsch, 2014).

\section{Hubungan kelayakan akademik dengan tahap efikasi}

Analisis korelasi membuktikan tidak terdapat hubungan di antara kelayakan akademik dengan tahap efikasi guru menjalankan PdPc pasca pandemik Covid-19. Bermaksud, kelayakan akademik bukan menjadi peramal kepada efikasi guru. Hasil yang sama diperoleh dalam kajian Mulok dan Yunus (2020) yang mengatakan tahap efikasi tidak dipengaruhi oleh kelayakan akademik dan pengalaman mengajar. Namun begitu keadaan ini berbeza dengan dapatan kajian Toran (2017) yang mendapati latar belakang akademik iaitu berkaitan dengan jenis program guru bergraduasi mempengaruhi tahap efikasi secara signifikan.

Tahap efikasi yang berada pada tahap sederhana tinggi mungkin disebabkan oleh sistem yang diamalkan oleh Unit Pendidikan Awal Kanak-Kanak di Jabatan KEMAS. Dimana, adanya bengkel dwi mingguan untuk semua guru tabika dan taska. Antara pengisian bengkel termasuklah berkaitan dengan pembangunan profesionalisme keguruan. Tanpa mengira kelayakan akademik, setiap guru memperoleh input yang sama iaitu berkaitan dengan profesionalisme di masa pandemik. Jika dilihat daripada kajian Yoo (2016), hasil kajian mendapati bahawa pembangunan profesionalisme guru mempunyai kesan positif ke atas efikasi guru.

Selain itu tahap efikasi yang sederhana tinggi juga mungkin disebabkan jumlah kehadiran kanakkanak yang sedikit ke Tabika. Bilangan yang sedikit, memudahkan guru mengawal kelas. Garis panduan pengoperasian semula tabika dan taska yang dikeluarkan oleh Jabatan KEMAS, tidak mewajibkan kehadiran kanak-kanak ke tabika. Kehadiran kanak-kanak adalah bergantung dengan kesediaan ibu bapa membenarkan anak mereka bersekolah. Malah kanak-kanak juga akan disaring setiap pagi, dan jika menunjukkan sebarang gejala mereka tidak dibenarkan untuk mengikuti kelas. Selain itu maksima kehadiran kanak-kanak sehari adalah seramai 15 orang, sekiranya keluasan kelas mencukupi. Sekiranya keluasan tidak mencukupi untuk penjarakan sosial maka daripada jumlah tersebut, kanak-kanak perlu hadir secara bergilir ke tabika.

\section{Hubungan pengalaman bekerja dengan tahap efikasi}

Sama seperti dapatan kajian Mulok dan Yunus (2020), kajian ini mendapati bahawa tidak terdapat hubungan di antara pengalaman bekerja dengan tahap efikasi guru menjalankan PdPc pasca pandemik Covid-19. Ini menunjukkan pengalaman mengajar tidak menentukan tahap efikasi guru.

Dapatan ini bertentangan dengan kajian Infurna, Riter, dan Schultz (2018) yang mendapati pengalaman mengajar mempunyai hubungan dengan tahap efikasi, dimana semakin tinggi pengalaman mengajar maka semakin kurang tahap efikasi guru menjalankan PdPc. Perbezaan dapatan kajian ini mungkin disebabkan, adanya pembangunan profesionalisme di kalangan guru yang dijalankan sebanyak dua kali setiap bulan. Kajian Yoo (2016) membuktikan efikasi mengajar meningkat dengan adanya pembangunan profesionalisme di kalangan guru. Walaupun bengkel dijalankan secara atas 
talian semasa negara berada dalam Perintah kawalan Pergerakan, guru tabika tidak mengalami masalah untuk menggunakan aplikasi seperti google meet untuk mengakses bengkel.

\section{Hubungan Kelayakan akademik dengan tahap efikasi mengikut dimensi efikasi}

Hasil kajian mendapati tiadanya hubungan antara kelayakan akademik dengan tahap efikasi dimensi penglibatan murid. Guru prasekolah dengan kelayakan akademik tinggi atau rendah tidak menjamin keyakinan mereka untuk memastikan adanya penglibatan aktif murid dalam aktiviti yang dijalankan semasa PdPC.

Dari segi dimensi arahan juga sama, iaitu tiada hubungan antara kelayakan akademik dengan efikasi dari segi strategi memberi arahan. Ini menunjukkan terdapat guru yang mempunyai efikasi tinggi, dan rendah dalam memastikan mereka dapat memberi arahan yang mudah kanak-kanak fahami dan patuhi, walaupun guru tersebut memiliki kelayakan akademik minima. Begitu juga dengan guru dari kumpulan akademik tinggi seperti diploma, dan ijazah. Tahap kelayakan akademik tidak menjadi indikator bahawa mereka akan mempunyai efikasi tinggi sesuai dengan jenis kelayakan akademik mereka, untuk memberi arahan dalam kelas yang dapat murid fahami dan ikuti.

Hubungan antara kelayakan akademik dengan dimensi efikasi pengurusan kelas juga tidak wujud. Ini menunjukkan kelayakan akademik tidak memberi kesan keatas tahap efikasi dari segi pengurusan kelas. Guru dengan kelayakan akademik minima boleh mempunyai efikasi tinggi atau rendah dalam mengurus kelas. Manakala guru dengan kelayakan akademik tinggi, atau khusus dalam bidang pendidikan awal kanak-kanak tidak menjamin adanya efikasi tinggi daripada mereka untuk mengurus kelas. Kerana terdapat guru dalam kumpulan ini yang menunjukkan efikasi rendah walaupun mempunyai kelayakan akademik tinggi.

\section{Hubungan pengalaman mengajar dengan tahap efikasi mengikut dimensi efikasi}

Hubungan antara pengalaman mengajar dengan dimensi efikasi penglibatan murid tidak wujud. Ini menunjukkan guru yang masih baru, dan guru yang mempunyai pengalaman mengajar lama boleh mempunyai efikasi yang tinggi mahupun rendah dari segi memastikan adanya penglibatan murid yang aktif dalam PdPc di kelas prasekolah pasca pandemik.

Hubungan antara pengalaman mengajar dengan efikasi dimensi strategi arahan juga tidak wujud. Ini menunjukkan tempoh pengalaman mengajar tidak dapat menjadi penentu sama ada guru mempunyai efikasi tinggi atau rendah dalam memberi arahan yang efektif. Terdapat guru yang sangat yakin mereka dapat menyedia dan memberi arahan yang dapat difahami dan dipatuhi oleh kanak-kanak walaupun mempunyai pengalaman mengajar yang kurang, dan ada juga yang tidak berkeyakinan walaupun tempoh mengajar guru tersebut sama

Keadaan ini berlainan dengan dapatan analisis hubungan di antara pengalaman mengajar dengan efikasi dalam dimensi pengurusan kelas. Walaupun pengalaman mengajar tidak mempunyai hubungan dengan tahap efikasi secara keseluruhan, namun keadaan ini berlainan jika dilihat dari segi dimensi efikasi tersebut. Kerana didapati bahawa terdapat hubungan di antara pengalaman mengajar dengan efikasi pengurusan kelas. Ini menunjukkan, semasa PdPc pasca Pandemik Covid-19, pengalaman mengajar guru menentukan efikasi kendiri mereka dalam pengurusan kelas. Semakin tinggi tempoh pengalaman mengajar guru, maka semakin tinggi efikasi mereka dalam mengurus kelas.

Situasi pandemik merupakan sesuatu yang baru dan asing bagi semua sektor, termasuklah dalam pendidikan sendiri. Dengan adanya kajian seumpama ini, maka wujudnya satu kajian rasmi berkenaan efikasi guru khususnya semasa pandemik. Pengetahuan berkenaan efikasi sangat penting kerana, efikasi kendiri guru memberi pengaruh yang kuat ke atas prestasi kerja guru (Dasan \& Md Nawi, 2020). Dapatan kajian ini merupakan dapatan yang khusus merujuk kepada situasi pandemik, dimana adanya norma baharu yang kontra dengan pelaksanaan PdPc yang sepatutnya dilaksanakan mengikut teori bidang pendidikan awal kanak-kanak. Dapatan ini dapat menjawab keraguan ibu bapa berkenaan keselamatan kanak-kanak menghadiri sekolah semasa pandemik. Seterusnya memberi keyakinan 
kepada ibu bapa untuk menghantar anak-anak mereka mengikuti sesi PdPc di kelas prasekolah. Hasil kajian ini boleh digunakan sebagai rujukan untuk pengubahsuaian atau penambahbaikan entiti pendidikan awal kanak-kanak. Sekiranya melihat kepada dapatan kajian, tahap efikasi guru tidak terjejas walaupun adanya pandemik. Oleh itu, strategi Bahagian Pendidikan Awal Kanak-kanak di Jabatan KEMAS, dalam mengekalkan kompetensi guru Tabika KEMAS wajar diteruskan, atau perlu diteliti semula bagi memastikan guru memiliki efikasi tinggi untuk menjalankan PdP pasca Pandemik Covid-19.

Pelbagai dimensi dalam bidang pendidikan wajar dikaji untuk melihat sama ada berlaku perbezaan sebelum pandemik dengan pasca pandemik. Ini kerana perubahan dalam landskap pendidikan pasca pandemik covid-19 memberi impak secara global. Jika dilihat dari sudut teori Herzberg, kewujudan pandemik yang masih belum terkawal merupakan faktor hygene atau masalah yang mampu mempengaruhi motivasi kerja seseorang. Kajian selanjutnya boleh dilaksana dengan mengambil kira prestasi kerja guru seperti yang terdapat dalam penilaian Sasaran Kerja Tahunan (SKT), serta prestasi kanak-kanak dalam Instrumen Pentaksiran Prasekolah Kebangsaan (IPPK) , dengan hasil dapatan kajian ini. Tujuannya bagi melihat hubungan antara tahap efikasi dengan prestasi sebenar kerja guru dan pencapaian kanak-kanak semasa pandemik. Ini kerana walaupun Bandura (1997) mengaitkan efikasi kendiri tinggi dengan hasil kerja positif namun, kajian Schilingger (2020) mendapati guru yang mempunyai efikasi kendiri tinggi kurang berkemahiran untuk menghasilkan kanak-kanak yang dapat membuat justifikasi ke atas penyelesaian matematik. Kajian khusus semasa pandemik Covid-19 pula mendapati, efikasi kendiri mempunyai kolerasi dengan komitmen kerja guru semasa pandemik Covid19 (Baloran \& Hernan, 2020).

Selain itu kajian yang sama sekiranya dilaksana pada masa hadapan, boleh ditambah dengan dimensi pengetahuan guru berkaitan pandemik Covid-19. Tujuannya agar kajian dapat dibuat ke atas hubungan tahap efikasi dengan pengetahuan guru berkenaan situasi semasa pandemik. Ini kerana sejak pandemik bermula, terdapat pelbagai varian baru virus yang muncul, malah gejala jangkitan juga didapati berbeza dengan apa yang diketahui di awal pandemik Covid-19. Kajian yang sama juga boleh dilaksanakan dengan membuat perbandingan antara institusi penyedia pendidikan awal kanak-kanak. Contohnya perbezaan efikasi antara guru di prasekolah swasta, badan bukan kerajaan, awam, ataupun perbezaan di antara penyedia pendidikan awal kanak-kanak di peringkat awam dengan awam. Hal ini kerana walaupun modul pembelajaran sama digunakan iaitu Kurikulum Standard Prasekolah Kebangsaan (KSPK), namun masing-masing mempunyai keunikan sendiri dalam menterjemah modul KSPK kepada PdPc di kelas prasekolah. Malah pengoperasian dari sudut teknikal atau bukan pengajaran juga berbeza antara setiap institusi pendidikan awal kanak-kanak ini.

\section{Rujukan}

Adamson, C. S., Chibale, K., Goss, R. J., Jaspars, M., Newman, D. J., \& Dorrington, R. A. (2021). Antiviral Drug Discovery: Preparing for The Next Pandemic. The Royal Society of Chemistry. doi:DOI: $10.1039 / \mathrm{d} 0 \mathrm{cs} 01118 \mathrm{e}$

Ahmad Zamri Khairani. (2016). Mengukur Efikasi Pengajaran Guru Pelatih Universiti Sains Malaysia. Asia Pacific Journal of Educators and Educations, 31, 15-25.

Bandura, A. (1997). Self-Efficacy the Exercise of Control. New York: W.H Freeman and Company.

Bandura, A. (2005). Adolescent development from an agentic prespective. In F. Pajaref, \& T. Urdan (Eds.), Self efficacy beliefs of adolescents (pp. 1-43). Connecticut: Information Age Publishing.

Beng, H. S., Wardle, L., \& Collie, P. (2020). Teachers Response to The School Reopening Strategy.

Berg, D. A., \& Smith, L. F. (2018). The Effect of School-Based Experience on Preservice Teachers' Self-Efficacy Beliefs. Issues in Educational Research, 28(3), 530-544.

Béteille, T., Ding, E., Molina, E., Pushparatnam, A., \& Wilichowsk, T. (2020). Three Principle To Support Teacher Effectiveness During Covid-19. Washington: World Bank.

Bouillet, D., Ivanec, T. P., \& Miljevic-Ridicki, R. (2014). Preschool teachers' resilience and their readiness for building children's resilience. Health Education, 114(6), 435-450.

Bray-Clark, N., \& Bates, R. (2003). Self-Efficacy Beliefs and Teacher Effectiveness: Implications for Professional Development. The Professional Educator, 26(1), 13-22. 
Bronfenbrenner, U. (1979). The Ecology of Human Development. Cambridge: Havard University Press.

Chua, B. S., Hj.Bahari, F. B., \& Mutang, J. A. (2016). SPSS Prinsip dan Analisis Data Dalam Sains Tingkah Laku. Kota Kinabalu: Penerbit UMS.

Cohen, L., Manion, L., \& Morrison, K. (2018). Research Methods in Education (8th ed.). New York: Routledge.

Cucinotta, D., \& Vanelli, M. (2020). WHO Declares COVID-19 a Pandemic. Acta Biomedica, 157160.

Dasan, N., \& Md Nawi, M. R. (2020). Hubungan Efikasi Kendiri Guru Dengan Prestasi Kerja Dalam Kalangan Guru Maktab Rendah Sains MARA (MRSM). JOurnal of Social Science and Humanities, 17(4), 173-187.

Dillman, D. A., Smyth, J. D., \& Christian, L. M. (2014). Internet, Phone, Mail and Mixed-Method Surveys. The Tailored Design Method. New Jersey: John Wiley \& Sons.

Dimitrios A, A. G., \& Koustelios, B. A. (2016). Background characteristics as predictors of Greek teachers' self-efficacy. International Journal of Educational Management, 30(3). doi:10.1108/IJEM-03-2014-0040

Gitman, L. J., McDaniel, C., Shah, A., Reece, M., Koffel, L., Talsma, B., \& Hyatt, J. C. (2018). Introduction to Business. Houston: OpenStax.

Hill, C. W., Jones, R. G., \& Schilling, M. A. (2015). Strategic Management Theory (11 ed.). Stanford: Cengage.

Hussin, F., Ali, J., \& Noor, M. Z. (2014). Kaedah Penyelidikan dan Analisis Data SPSS. Sintok: Penerbit Universiti Utara Malaysia.

Infurna, C. J., Riter, D., \& Schultz, S. (2018). Factors that Determine Preschool Teacher Self-Efficacy in an Urban School District. International Electronic Journal of Elementary Education, 11(1), 17. doi:10.26822/iejee.2018143929

Jabatan Kemajuan Masyarakat. (2020). Garis Panduan Pelaksanaan Pengoperasian Semula Tabika dan Taska Jabatan Kemajuan Masyarakat . Putrajaya.

Jongkulin, M., Talip, R., \& Taat, M. (2019). Pendidikan Inklusif: Efikasi Kendiri Guru Prasekolah. Malaysian Journal of Social Sciences and Humanities, 4(7), 87-95.

KDN. (30 11, 2020). Kementerian Dalam Negeri : Ministry of Home Affairs. Retrieved from National Key Result Area (NKRA) Division: http://www.moha.gov.my/index.php/en/public

Kementerian Pendidikan Malaysia . (2013). Pelan Pembangunan Pendidikan Malaysia 2013-2025 (Pendidikan Prasekolah Hingga Lepas Menengah). Putrajaya: Kementerian Pendidikan Malaysia.

Kementerian Pendidikan Malaysia. (2021). Retrieved 5 Febuari, 2021, from MOE: https://www.moe.gov.my/en/muat-turun/pekeliling-dan-garis-panduan/4109-garis-panduanpengurusan-dan-pengoperasian-sekolah-dalam-norma-baharu-2-0/file

Krejcie, R. V., \& Morgan, D. W. (1970). Determining Sample Size For Research Activities. Educational and Psychological Measurement, 30, 607-610.

Levine, L. E., \& Munsch, J. (2014). Child development. Northridge: Sage Publication.

Masten, A. S. (2014). Ordinary magic: Resilience in development. New York: Guilford.

Mooney, G. C. (2013). Theories of Childhood. Yorkton: Redleaf Press.

Mortimore, P. (1993). School effectiveness and the management of effective learning and teaching. The International Congress for School Effectiveness and Improvement . Norrkoping, Sweden.

Mulok, J. L., \& Yunus, F. (2020). Efikasi Kendiri Guru Prasekolah Dalam Mengajar Bahasa Inggeris. Jurnal Dunia Pendidikan, 2(2), 187-195.

Nunnally, J. C., \& Bernstein, I. H. (1994). Psychometric theory (3rd ed.). New York: McGraw Hill.

Rogers, B. (2015). Classroom Behavior: A Practical Guide To Effective Teaching, Behavior Management and Colleague Support. London: Sage.

Salleh, S., \& Abdullah, N. (2015). Cost vsQuality of Service: A Study Of Internet User In Rural Sabah, Malaysia. Proceedings of INTCESS15-2nd International Conference on Education and Social Sciences, 401-412.

Santrock, J. W. (2011). Child Development. New York: McGraw Hill.

Schilingger, T. (2020). Self efficacy of kindergarten teachers mathematical instruction. Early Childhood Education Journal, 49, 623-632.

Toran, M. (2017). An Analysis of Preschool Teachers' Sense of Efficacy: A Case of TRNC. Journal of Education and Training Studies, 5(4), 121-131. doi:10.11114/jets.v5i4.2171 
Toran, M., \& Gencgel, H. (2016). An evaluation of preschool teachers' clasroom manangement skills:TRNC sample. Kastamonu Education Journal, 24(4), 2041-2056.

Tschannen-Moran, M., \& Hoy, A. W. (2001). Teacher Efficacy: Capturing an Elusive Construct. Teaching and Teacher Education, 17, 783-805.

UNESCO. (2020). Education IN a Post Covid World: Nine Ideas for Public Action. Paris: UNESCO.

Wai-Hung, L. (2012). The Study of Teacher Efficacy in Hong Kong Sub-Degree Sector. Education Research International, 2012, 1-6. doi:doi:10.1155/2012/265293

Woodcock, S., \& Jones, G. (2020). Examining the Interrelationship Between Teachers' Self-Efficacy and Their Beliefs Towards Inclusive Education for All. Teacher Development, 24(4), 583-602. doi:10.1080/13664530.2020.1803957

Yoo, J. H. (2016). The Effect of Professional Development on Teacher Efficacy and Teachersí SelfAnalysis of Their Efficacy Change. Journal of Teacher Education for Sustainability, 18(1), 8494. doi:DOI: $10.1515 /$ jtes-2016-0007

Zai, S. A., \& Munshi, P. (2016). Construct Validity to Examine the Latent Traits of Teacher Self Efficacy Instrument. Advances in Social Sciences Research Journal, 3(4), 74-83. doi:10.14738/assrj.34.1944 